\title{
SUPRAORBITAL NEURALGIA: SEBUAH LAPORAN KASUS
}

\author{
Made Gemma Daniswara Maliawan \\ Fakultas Kedokteran Universitas Udayana Bali \\ gemma.daniswara@gmail.com
}

\begin{abstract}
ABSTRAK
Latar Belakang: Supraorbital neuralgia (SON) merupakan penyakit yang memiliki kriteria nyeri kepala depan pada daerah yang dipersarafi oleh saraf orbital, sensitif terhadap nyeri pada celah supraorbital atau sepanjang saraf supraorbital, dan hilangnya gejala secara absolut namun sementara jika dilakukan blok saraf supraorbital. SON merupakan penyakit yang langka, sehingga melatar belakangi penulis untuk melaporkan kasus ini.
\end{abstract}

Kasus: Seorang laki-laki 52 tahun, datang dengan keluhan utama nyeri kepala sebelah kanan sejak 7 tahun yang lalu. Nyeri dirasakan seperti ditusuk-tusuk dan menetap. Pada pemeriksaan fisik, keadaan umum pasien dalam batas normal, dan didapatkan daerah sensitif nyeri pada alis sebelah kanan dan sepanjang persarafan saraf supraorbital pada pemeriksaan lokal. Pemeriksaan radiologi dan MRI kepala tidak menunjukkan kelainan. Pada pasien kemudian dilakukan neurektomi saraf supraorbital. Kondisi pasca neurektomi pada pasien ini baik, pasien bebas nyeri, dan luka operasi terawat baik.

Simpulan: Neurektomi saraf supraorbital merupakan tindakan yang aman, cepat, dan minim efek samping bagi pasien dengan SON.

Kata kunci: supraorbital, neuralgia, pembedahan, neurektomi

\section{ABSTRACT}

Background: Supraorbital neuralgia (SON) is a disease caracterized by forehead pain in the area innervated with supraorbital nerve, tenderness on supraorbital notch or along supraorbital nerve, and absolut, but transitory relief of symptoms with supraorbital nerve blockade. Less epidemiological data suggested SON is rare disease.

Case: A 52 years-old male patient present with a history of right side headache since 7 years ago. The pain was continous and stabbing pain. General physical examination is within normal limit, and local examination found tenderness on supraorbital notch and along the supraorbital nerve. Radiology and MRI examination showed no defect. The patient than treated with supraorbital neurectomy. Postoperative condition was good, the patient is pain free, and postoperative wound is treated appropiately.

Conclusion: Supraorbital neurectomy is safe, quick, and less side effect in patient with SON.

Keywords: supraorbital, neuralgia, surgery, neurectomy

\section{PENDAHULUAN}

Supraorbital Neuralgia (SON) merupakan jenis neuralgia yang memiliki karakteristik nyeri persisten pada alis dan dahi sesuai dengan distribusi saraf supraorbital. $^{1}$ Saraf supraorbital dibentuk dari serabut-serabut saraf frontal yang merupakan cabang dari saraf oftalmikus $\left(\mathrm{V}_{1}\right)$. Saraf frontal bercabang menjadi dua, yaitu saraf supratroklear dan supraorbital. Saraf supraorbital keluar dari rongga mata melalui foramen atau celah supraorbital dan berlanjut ke arah superior mempersarafi kelopak mata bagian atas, dahi, dan kulit kepala bagian depan. ${ }^{1,2}$

Kurangnya data epidemiologi, menunjukkan SON merupakan penyakit yang langka. ${ }^{2}$ Onset dari penyakit ini berkisar antara umur 40 hingga 50 tahun dengan wanita sebagai penderita tersering. ${ }^{3}$ SON memiliki tiga kriteria klinis sebagai diagnosis, yaitu: $:^{1,3}$ 1) nyeri kepala depan pada daerah yang dipersarafi oleh saraf orbital tanpa disertai perpindahan sisi; 2) Sensitif terhadap nyeri pada celah supraorbital atau sepanjang saraf supraorbital; 3) hilangnya gejala 
secara absolut atau sementara jika dilakukan blok saraf supraorbital dengan berbagai cara. Oleh karena SON merupakan penyakit yang langka, kasus pada laporan ini layak untuk dilaporkan.

\section{KASUS}

Pasien laki-laki 52 tahun, suku Bali datang dengan keluhan utama nyeri kepala sebelah kanan mulai dari alis ke atas hingga temporal kanan sejak 7 tahun yang lalu. Nyeri dirasa seperti tertusuk-tusuk, menetap, dan mengganggu aktivitas sehari-hari. Pasien tidak memiliki riwayat trauma kepala dan keluhan penyakit sistemik lainnya. Pasien telah berobat ke banyak dokter dan pengobatan tradisional, namun tidak berpengaruh terhadap penyakitnya.

Pada pemeriksaan fisik, tanda-tanda vital dalam batas normal, pemeriksaan sistem-sistem tubuh yang lain dalam batas normal, dan pemeriksaan neurologi dalam batas normal. Pemeriksaan lokal didapatkan daerah sensitif nyeri pada alis sebelah kanan dan sepanjang persarafan saraf supraorbital.

Pemeriksaan laboratorium dalam batas normal, pemeriksaan radiologi dan MRI tidak ditemukan kelainan pada kepala. Selanjutnya, dilakukan blok saraf supraorbital dengan suntikan lidocain pada daerah foramen orbital. Nyeri yang dirasakan pasien menghilang segera setelah blok saraf supraorbital dilakukan. Tiga kriteria diagnosis telah dipenuhi, oleh karena itu pasien didiagnosis SON.

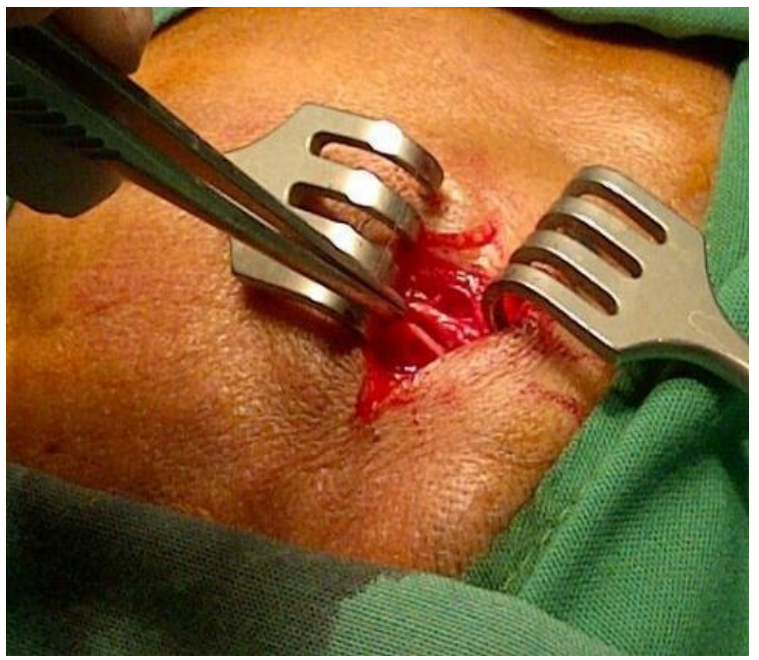

Gambar I. Saraf supraorbital dijepit dengan pinset.

(Dokumentasi Penulis)

Pada pasien kemudian dilakukan tindakan neurektomi saraf supraorbital. Tindakan dilakukan dengan anestesi lokal menggunakan lidocain dan melakukan insisi alis bagian atas untuk menemukan saraf supraorbital. Setelah teridentifikasi, saraf tersebut di potong dan diavulsi dengan menggunakan klem arteri. Penjahitan dua lapis dilakukan untuk menutup luka insisi. Pasien diizinkan pulang pada hari itu juga. Penyembuhan luka operasi berjalan baik dan pasien telah bebas nyeri selama 5 bulan. Efek samping yang dirasakan adalah rasa tebal pada dahi dan temporal kanan yang menghilang setelah 2 bulan.

\section{DISKUSI}

SON dikenal juga dengan sebutan swimmer's headache atau goggle headache. Sebutan ini didapat dari dua laporan ahli saraf pada tahun 1983 yang mengalami keluhan neuralgia sepanjang distribusi saraf supraorbital setelah berenang menggunakan kacamata renang (goggles) yang terlalu erat dan tidak pas. ${ }^{4}$ Trauma pada wajah dapat menimbulkan SON. Pada suatu studi epidemiologi didapatkan 10 dari 12 pasien SON memiliki riwayat trauma pada wajah. ${ }^{5}$ Pemakaian helm yang terlalu erat, kacamata yang tidak pas, dan retensi cairan juga dapat memicu SON. ${ }^{6}$

Diagnosis SON ditegakkan berdasarkan kriteria Headache Classification Subcommittee of the International Headache Society antara lain 1) nyeri yang tiba- tiba atau konstan di regio celah supraorbital dan aspek medial dari kepala depan pada area yang dipersarafi oleh saraf supraorbital, 2) sensitif terhadap nyeri pada daerah celah supraorbital, 3) nyeri menghilang dengan blok anestesi lokal atau ablasi saraf supraorbital. ${ }^{7}$ Pada SON primer, nyeri yang dirasakan paling sering bersifat kronik dan terus-menerus, sedangkan nyeri yang bersifat paroksismal dan berdurasi pendek jarang terjadi. Intensitas nyeri yang pernah dilaporkan antara parah hingga amat parah. ${ }^{3}$ Pada SON sekunder yang disebabkan oleh trauma, nyeri yang sering dirasakan bersifat intermiten (70\%) dan berselang (30\%) dengan intensitas nyeri antara ringan hingga sedang. ${ }^{5}$

Diagnosis banding dari SON antara lain trigeminal neuralgia (TN) dengan manifestasi pada divisi $\mathrm{V}_{1}$, Suprathroclear neuralgia (STN), sinusitis frontal, dan hemicrania continua (HC). ${ }^{2,6}$ TN biasanya bersifat unilateral dan menyerang divisi $\mathrm{V}_{2}(35 \%), \mathrm{V}_{3}(30 \%), \mathrm{V}_{2}$ dan $V_{3}(20 \%), V_{1}$ dan $V_{2}(10 \%)$, dan $V_{1}(4 \%) .{ }^{1}$ Durasi dari serangan TN memiliki rata-rata 6,5 detik dengan 
rentang 2 hingga 32 detik. Berbeda dengan TN, pada SON tidak ditemukan tanda-tanda khas seperti trigger zone, tic pada bagian wajah yang terserang, dan nyeri saat diprovokasi oleh sentuhan ringan atau saat mengunyah. ${ }^{2}$

STN sulit dibedakan dari SON karena letak anatominya yang berdekatan, namun berdasarkan observasi dari Pareja dan Caminero nyeri pada STN dirasakan pada bagian medial dan ditambah dengan blok pada saraf supratroklear yang akan menghilangkan nyeri. ${ }^{3}$ Pada HC, nyeri yang dialami memiliki karakteristik unilateral, terus-menerus, dan responsif terhadap obat indometasin.

Terapi SON biasanya dimulai dengan menghindari pencetus seperti trauma berulang, helm yang terlalu ketat, dan kacamata yang tidak pas. Bersamaan dengan itu, dapat dilakukan pemberian obat anti kejang seperti gabapentin, pregabalin, atau carbamazepin. ${ }^{4}$ Pemberian pregabalin atau gabapentin pada pasien-pasien TN dan post-herpetic neuralgia (PSH) menunjukkan hasil yang memuaskan, namun studi klinis pada pasien SON yang dilakukan oleh Caminero menunjukkan pengobatan dengan gabapentin atau pregabalin terbukti gagal pada beberapa pasien. ${ }^{8,9}$

Blok saraf supraorbital dengan injeksi bupivacaine dan triamcinolone acetat dapat berfungsi ganda sebagai diagnosis dan terapi. ${ }^{2}$ Nyeri akan hilang segera setelah tindakan dilakukan, namun tidak permanen sehingga perlu diberikan injeksi ulang jika pasien merasa sakit kembali. ${ }^{2,6}$ Tindakan pembedahan dapat digunakan jika semua pilihan pengobatan dan terapi injeksi tidak berhasil atau pasien mengalami alergi. ${ }^{10}$

Salah satu tindakan pembedahan non-invasif pada pasien dengan neuralgia adalah neurektomi perifer, disamping injeksi alkohol dan radiofrekuensi selektif termokoagulasi. ${ }^{11}$ Neurektomi perifer merupakan tindakan pembedahan yang paling simpel, aman, dan minim efek samping. ${ }^{1,12}$ Pada salah satu studi retrospektif pada 28 pasien TN yang dilakukan neurektomi perifer, 2 (6,66\%) pasien yang mengalami kekambuhan setelah 1 tahun, sedangkan 26 pasien masih bebas nyeri setalah 3 tahun pasca pembedahan. $^{12}$ Komplikasi yang pernah dilaporkan setelah tindakan neurektomi perifer antara lain hemoragi lokal, diplopia transien, rasa tebal atau anestesia pada kulit yang dipersarafi saraf supraorbital, dimana berlangsung hanya untuk beberapa hari. ${ }^{1}$ Komplikasi ini lebih ringan dibanding injeksi alkohol dimana dapat terjadi resiko tinggi kekambuhan dan nekrosis jaringan sekitar. ${ }^{13}$ Radiofrekuensi termokoagulasi pada pasien TN telah terbukti sangat efektif, beresiko rendah, dan minim efek samping. ${ }^{14}$ Tindakan radiofrekuensi dapat digunakan pada pasien SON untuk mencapai hilangnya gejala dalam jangka waktu yang lama, namun terdapat batasan dalam penggunaannya karena terbatasnya ketersediaan alat dan biaya yang tinggi. ${ }^{2}$

\section{SIMPULAN}

Diagnosis yang tepat sangat penting untuk menetapkan pilihan terapi. Terapi bedah dapat dipilih jika pasien gagal dengan terapi farmakologis atau pasien alergi terhadap pengobatan yang diberikan. Neurektomi saraf supraorbital merupakan tindakan yang aman, cepat, dan minim efek samping bagi pasien dengan SON.

\section{DAFTAR PUSTAKA}

1. Agrawal SM, Kambalimath DH. Trigeminal neuralgia involving supraorbital and infraorbital nerve: case report. NJMS. 2010;1:179-182.

2. Jadhav V, Patil D, Mane M. Supraorbital neuralgia: case report. Med J DY Patil Univ. 2014;7:208-10.

3. Pareja JA, Caminero AB. Supraorbital neuralgia. Curr Pain Headache Rep. 2006;10:302-5.

4. O'Brien JC. Swimmer's headache or supraorbital neuralgia. Proc (Bayl Univ Med Cent). 2004;17:418-19.

5. Spaastad O, Petersen HC, Bakkeleig IS. Supraorbital neurologi: Vågå study of headache epidemiology. Cephalgia. 2004;25:296-304.

6. Trescot AM. Headache management in an interventional pain practice. Pain Physician. 2000;3:197-200.

7. Headache Classification Committe of the International Headache Society: Classification and Diagnostic Criteria for Headache Disorders, Cranial Neuralgias, and Facial Pain, 2nd. Edition. Cephalgia. 2004;24(suppl1):9-160.

8. Singh S, Gupta R, Kaur S, Kaur J. Postherpetic neuralgia: a review of current management strategies. Indian J Pain. 2013;27:12-21.

9. Caminero $A B$, Pareja JA. Supraorbital neuralgia: a clinical study. Cephalgia.2001;21:216-23.

10. Cerovic R. Neurectomy of the trigeminal nerve branches: clinical evaluation of an absolut 
treatment. J Cranio-Maxilofac Surg. 2009;37:38891.

11. Bagheri S, Farhidvash F, Perciaccante V. Diagnosis \& treatment of patients with trigeminal neuralgia. J Am Dent Assoc. 2004;135:1713-1717.

12. Agrawal SM, Kambalimath DH. Peripheral neurectomy: a minimally invasive treatment for trigeminal neuralgia. A retrospective study. J Maxillofac Oral Surg. 2011;10(3):195-98.
13. Nurmikko TJ, Eldridge PR. Trigeminal neuralgia: pathophysiology, diagnosis, amd current treatment. Br J Anesth. 2001;87(1):117-132.

14. Fouad W. Management of trigeminal neuralgia by radiofrequency thermocoagulation. Alexandria Journal of Medicine.2011;47(1):79-86. 